\title{
A novel assay for apoptosis \\ Flow cytometric detection of phosphatidylserine expression on early apoptotic cells using fluorescein labelled Annexin V
}

\author{
István Vermes ${ }^{\text {¿'* }}$, Clemens Haanen ${ }^{\text {a }}$, Helga Steffens-Nakken ", \\ Chris Reutelingsperger ${ }^{b}$ \\ ${ }^{a}$ Department of Clinical Chemistry, Medical Spectrum Twente, P.O. Box 50.000, 7500 KA Enschede, Netherlands \\ ${ }^{\mathrm{b}}$ Department of Biochemistry, Cardiovascular Research Institute Maastricht (CARIM), State University Limburg. Maastricht, \\ Netherlands
}

Received 3 October 1994; revised 2 December 1994; accepted 16 March 1995

\begin{abstract}
In the early stages of apoptosis changes occur at the cell surface, which until now have remained difficult to recognize. One of these plasma membrane alterations is the translocation of phosphatidylserine (PS) from the inner side of the plasma membrane to the outer layer, by which PS becomes exposed at the external surface of the cell. Annexin $\mathrm{V}$ is a $\mathrm{Ca}^{2+}$ dependent phospholipid-binding protein with high affinity for PS. Hence this protein can be used as a sensitive probe for PS exposure upon the cell membrane. Translocation of PS to the external cell surface is not unique to apoptosis, but occurs also during cell necrosis. The difference between these two forms of cell death is that during the initial stages of apoptosis the cell membrane remains intact, while at the very moment that necrosis occurs the cell membrane looses its integrity and becomes leaky. Thereforc the measurement of Annexin $\mathrm{V}$ binding to the cell surface as indicative for apoptosis has to be performed in conjunction with a dye exclusion test to establish integrity of the cell membrane.

This paper describes the results of such an assay, as obtained in cultured HSB-2 cells, rendered apoptotic by irradiation and in human lymphocytes, following dexamethasone treatment. Untreated and treated cells were evaluated for apoptosis by light microscopy, by measuring the amount of hypo-diploid cells using of DNA flow cytometry (FCM) and by DNA electrophoresis to establish whether or not DNA fragmentation had occurred. Annexin $\mathrm{V}$ binding was assessed using bivariate FCM, and cell staining was evaluated with fluorescein isothiocyanate (FITC)-labelled Annexin V (green fluorescence), simultaneously with dye exclusion of propidium iodide (PI) (negative for red fluorescence). The test described, discriminates intact cells ( $\mathrm{FITC}^{-} / \mathrm{PI}^{-}$), apoptotic cells $\left(\mathrm{FITC}^{+} / \mathrm{PI}{ }^{-}\right.$) and necrotic cells ( $\left.\mathrm{FITC}^{+} / \mathrm{PI}^{+}\right)$. In comparison with existing traditional tests the Annexin $\mathrm{V}$ assay is sensitive and easy to perform. The Annexin $\mathrm{V}$ assay offers the possibility of detecting early phases of apoptosis
\end{abstract}

Abbreviations: FCM, flow cytometry; PI, propidium iodide; FITC, fluorescein isothiocyanate; PS, phosphatidylserine

* Corresponding author. Tel.: 00-31-53-873400; Fax: 00-31-53-873075. 
before the loss of cell membrane integrity and permits measurements of the kinetics of apoptotic death in relation to the cell cycle. More extensive FCM will allow discrimination between different cell subpopulations, that may or may not be involved in the apoptotic process.

Keywords: Apoptosis; Annexin-V; Flow cytometry; Phosphatidylserine

\section{Introduction}

There is little quantitative data about the occurrence, duration and frequency of apoptosis in tissues and tumors compared to our knowledge about cell proliferation (Leoncini et al., 1993). The very nature of the process of apoptosis explains this lack of knowledge. Apoptosis involves scattered single cells in which the early stages evanesce to recognition and the end-stage apoptotic bodies undergo rapid phagocytosis. The duration of the whole event takes no more than a few hours and last, but not least, this type of cell loss takes place in the absence of any inflammatory reaction (Wyllie et al., 1980).

A variety of methods exists to obtain information about cell proliferation (Gerdes et al., 1983; Begg et al., 1985; Hall and Levison, 1990; Woods et al., 1991), but assays which provide quantitative data about apoptosis lack specificity, are time consuming and usually require the destruction of cell integrity (Sarraf and Bowen, 1988; DelVecchio et al., 1991; Facchinetti et al., 1991; Nicoletti et al., 1991; Telford et a1., 1991,1992; Darzynkiewicz et al., 1992; Meyaard et al., 1992; Olive et al., 1993; Ormerod et al., 1993; Wijsman et al., 1993; Hotz et al., 1994; Schmid et al., 1994).

Changes on the surface of apoptotic cells, such as the expression of thrombospondin binding sites (Pytela et al., 1985), loss of sialic acid residues (Savill et al., 1993) and exposure of phosphatidylserine (Fadok et al., 1992) have been difficult to recognise. Phosphatidylserine (PS) is a negatively charged phospholipid, that is normally predominantly present in membrane leaflets facing the cytosol (Op den Kamp, 1979). Surface exposure of PS has been reported for activated platelets and senescent erythrocytes (Schroit and Zwaal, 1991) and recently it was shown by Fadok et al. (1992) that cells undergoing apoptosis break up the phospholipid asymmetry of their plasma membrane to expose PS.

Annexin $\mathrm{V}$ was initially discovered as a vascular protein with strong anticoagulant properties (Reutelingsperger et al., 1985). It appeared to belong to a multigene family of proteins defined by a repeated sequence motif, originally termed the endonexin loop (Geisow et al., 1986). The annexins have the biological property of binding to phospholipids in a $\mathrm{Ca}^{2+}$-dependent way (Raynal and Pollard, 1994). Annexin V binds preferentially to phospholipid species such as PS, which is normally absent in the outer leaflet of the plasma membrane (Tait et al., 1989; Andree et al., 1990) and shows minimal binding to phospholipid species such as phosphatidylcholine and sphingomyeline, which are constitutively present in the outer leaflet of plasma membranes.

When cell death occurs, PS is translocated to the outer layer of the membrane i.e. the external surface of the cell. This occurs in the early phases of apoptotic cell death during which the cell membrane itself remains intact. Necrosis, on the other hand, is accompanied by loss of cell membrane integrity and leakage of cellular constituents into the environment. Therefore we have reasoned that measurement of Annexin $\mathrm{V}$ binding, executed simultaneously with a dye exclusion test, would provide a perfect assay to detect apoptotic cells and to discriminate between apoptosis and necrosis.

This paper describes the results of a novel assay for the detection of apoptosis, based upon Annexin $\mathrm{V}$ binding to the apoptotic cells. The test was executed on cultured HSB- 2 cells rendercd apoptotic by irradiation and on human lymphocytes treated with dexamethasone. Untreated and treated cells were evaluated by light microscopy for the occurrence of morphological changes consistent with apoptosis, by DNA flow cytometry (FCM) for the occurrence of hypo-di- 
ploid cells, and by electrophoresis of extracted DNA for the presence of DNA fragmentation. With use of bivariate FCM we simultaneously measured in the various cell populations staining with fluorescein isothiocyanite (FITC)-labeled Annexin V (green fluorescence) and dye exclusion of the non-vital dye propidium iodide (PI) (red fluorescence negative). The test is easy to perform and discriminates between intact cells $\left(\mathrm{FITC}^{-} / \mathrm{PI}^{-}\right)$, apoptotic $\left(\mathrm{FITC}^{+} / \mathrm{PI}^{-}\right)$and necrotic cells (FITC ${ }^{+} / \mathrm{PI}^{+}$).

\section{Materials and methods}

\subsection{Experimental design}

Cultured cells of the HSB-2 human leukemia cell line were rendered apoptotic using irradiation at doses of 2, 4, 6, 8 Gy and apoptosis of normal human lymphocytes was induced by incubation with dexamethasone $(100 \mu \mathrm{M})$ for up to $96 \mathrm{~h}$. The occurrence and amount of apoptosis was assessed at regular intervals (1) by light microscopy of cytocentrifuge preparations, (2) by measurement of the percentage of hypo-diploid cells using of DNA-FCM and (3) by assessment of DNA fragmentation as demonstrated by the typical ladder pattern observed following DNA electrophoresis. These data were compared with the results, obtained with the Annexin $\mathrm{V}$ binding test in the novel assay as described in this paper.

\subsection{Cell line and cell culture conditions}

The T lymphoblastoid cell line CCRF-HSB-2 was obtained from the American Type Culture Collection (ATCC, Rockville, MD). The HSB-2 cell culture was maintained in exponential growth in RPMI 1640 medium (Flow Labs, Irvine, Scotland) supplemented with $10 \%(\mathrm{v} / \mathrm{v})$ heat inactivated $\left(30 \mathrm{~min}, 56^{\circ} \mathrm{C}\right)$ fetal bovine serum (FBS) (Gibco, Grand Island, NY), $100 \mu \mathrm{g} / \mathrm{ml}$ streptomycin, $100 \mathrm{IU} / \mathrm{ml}$ penicillin and $2 \mathrm{mM}$ L-glutamine (Flow Labs, Irvine, Scotland). Cells were cultured in a $5 \% \mathrm{CO}_{2}-95 \%$ air, fully humidified atmosphere at $37^{\circ} \mathrm{C}$.

\subsection{Isolation of peripheral human lymphocytes}

Blood mononuclear cells were isolated from buffy coats of peripheral blood of healthy volunteers. After density centrifugation on $1.077 \mathrm{~g} / \mathrm{ml}$ Ficoll (Sigma Chemical Company, St. Louis) the interphase cells were removed and resuspended in RPMI (Flow Labs, Irvine, UK). Lymphocytes were enriched by removal of the adherent mononuclear cells by incubation of the cell suspension at $37^{\circ} \mathrm{C}$ for $1 \mathrm{~h}$ in a polystyrene tissue culture flask. The non-adherent lymphocytes in the supernatant were collected. The cells were maintained in a $5 \% \mathrm{CO}_{2}-95 \%$ air, fully humidified atmosphere at $37^{\circ} \mathrm{C}$ at a final cell concentration of $\pm 10^{6}$ cells $/ \mathrm{ml}$.

\subsection{Irradiation}

Cell suspensions, as described, were irradiated in plastic bags using a linear accelerator (Varian Clinac 2100.C, Varian, Palo Alto, CA) with an energy of $6 \mathrm{MV}$, at a mean distance to target of $100 \mathrm{~cm}$ and a dose rate of $4.0 \mathrm{~Gy} / \mathrm{min}$ up to 2,4 . 6 and 8 Gy per cell sample.

\subsection{Light microscopy}

After radiation or dexamethasone exposure, the cells under investigation were centrifuged at $600 \mathrm{rpm}$, using a Shandon cytocentrifuge (Shandon, Pittsburg, PA). The cells were fixed in $100 \%$ methanol, stained with May Grünwald-Giemsa and examined for nuclear changes, consistent with apoptosis (Sarraf and Bowen, 1988; Arends et al., 1990; DelVecchio et al., 1991). 200 cells were evaluated per specimen.

\subsection{FCM measurement of hypo-diploid nuclei}

Apoptotic cells can be recognized and distinguished from necrotic cells using FCM of cellular DNA. Apoptotic cells show a diminished staining below the $G_{0} / G_{1}$ population of normal diploid cells. The DNA specific fluorochrome PI identified a distinct hypo-diploid cell population, which we have designated ' $A_{0}$ cells'. The percentage of 

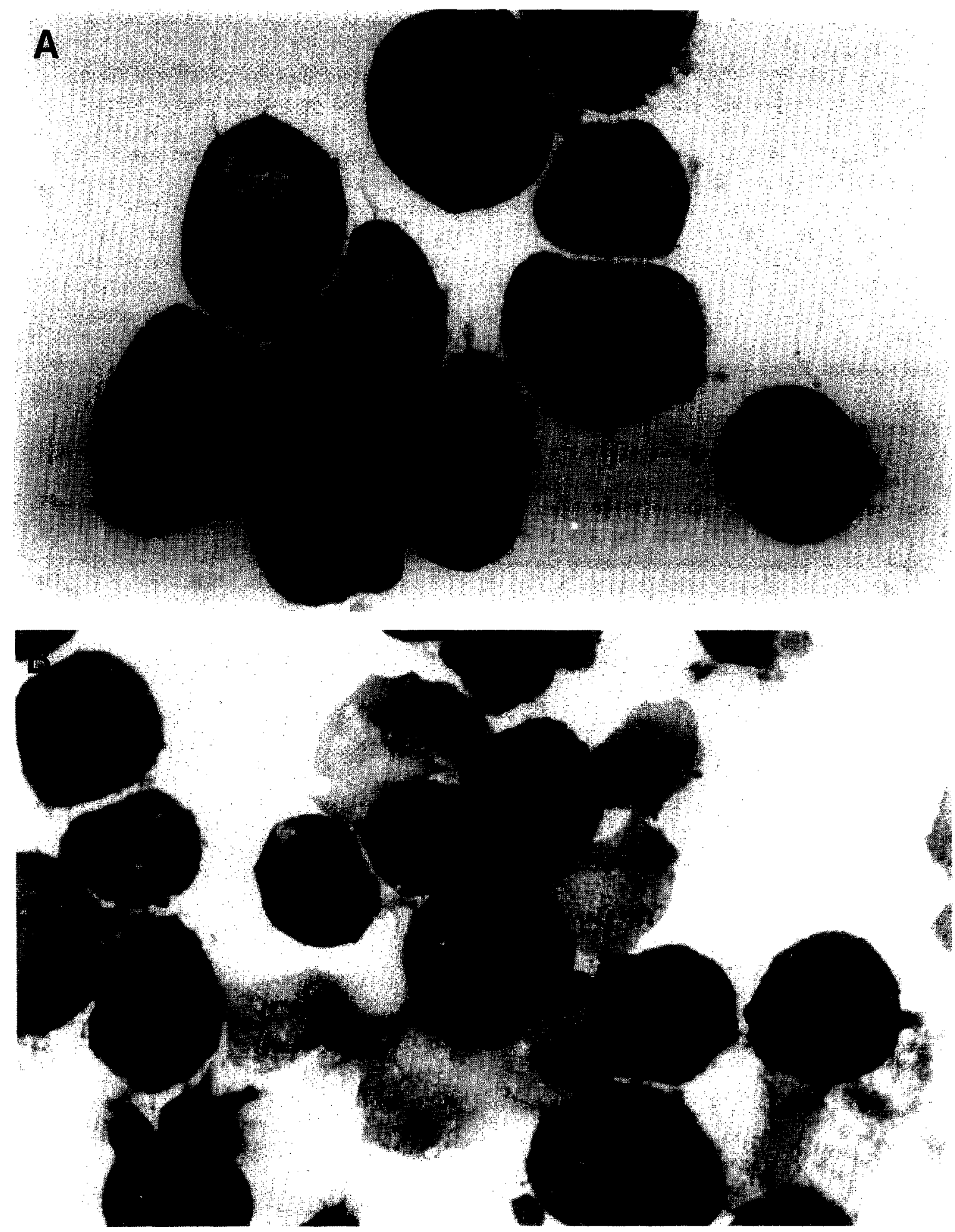

Fig. 1 (continued on next page). 

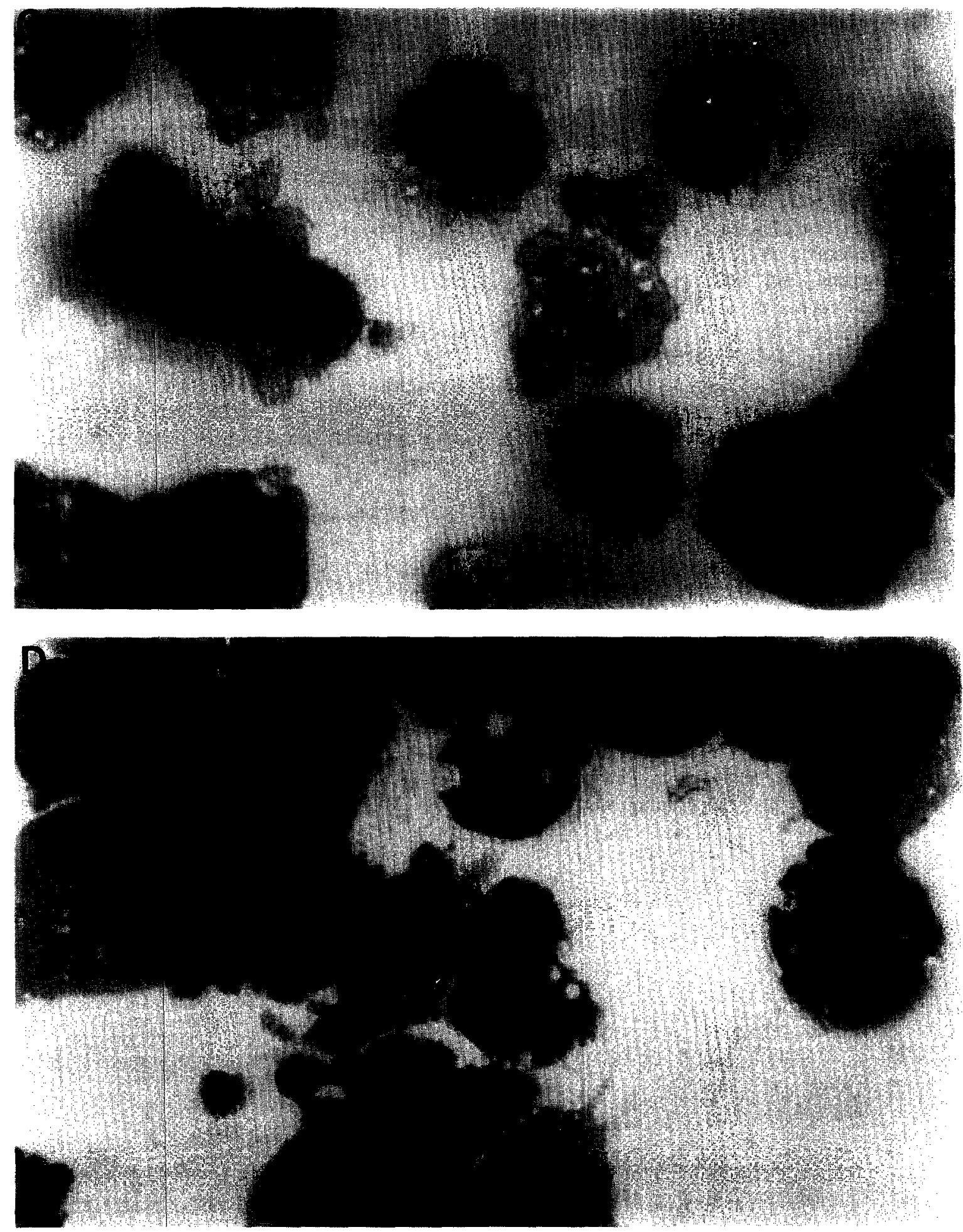

Fig. 1. Intact HSB-2 cells $(A)$; necrotic cells $24 \mathrm{~h}$ after sodium azide treatment $(B)$ and $24 \mathrm{~h}$ after irradiation with $8 \mathrm{~Gy}(C)$; apoptotic cells 8 h after irradiation with $8 \mathrm{~Gy}(D)$. 
$A_{o}$ cells was measured according to Nicoletti et al. (1991). $3.0 \times 10^{6}$ cells were evaluated as follows: after washing with phosphate buffered saline (PBS), the cells were centrifuged $(200 \times g)$ and gently resuspended in $1.5 \mathrm{ml}$ hypotonic PI solution (PI $50 \mu \mathrm{g} / \mathrm{ml}$ in $0.1 \%$ sodium citrate plus $0.1 \%$ Triton $\mathrm{X}-100$, Sigma) in polypropylene tubes. The tubes were then placed at $4^{\circ} \mathrm{C}$ in the dark overnight. The PI fluorescence of individual nuclei was measured by FCM (FACScan, Becton Dickinson Systems, San José, CA) using program consort 30 and registered on a logarithmic scale.

\subsection{Measurement of DNA fragmentation}

DNA fragmentation was analyzed with slight modifications according to Miller et al. (1988). In short: $8 \times 10^{6}$ washed cultured cells were incubated in $1 \mathrm{ml}$ digestion buffer $(50 \mathrm{mM}$ Tris- $\mathrm{HCl}$, pH $8.0150 \mathrm{mM} \mathrm{NaCl}, 5 \mathrm{mM}$ EDTA- $\mathrm{Na}_{2}, 0.2 \mathrm{mg}$ proteinase $\mathrm{K}, 120 \mu \mathrm{l}$ SDS $10 \%$ ) at $37^{\circ} \mathrm{C}$ overnight. $340 \mu 16 \mathrm{M} \mathrm{NaCl}$ were added to the tube and shaken vigorously for $15 \mathrm{~s}$. After centrifugation at $2500 \mathrm{rpm} / 15 \mathrm{~min}$ the supernatant containing DNA was transferred to another tube and the procedure, repeated until no precipitated protein pellet was formed.

After the addition of 2 vols. $100 \%$ ethanol, the tube was placed on ice for $30 \mathrm{~min}$ and then centrifuged for $10 \mathrm{~min} 12000 \mathrm{rpm}$. The precipitate was washed with $70 \%$ ethanol and cen- trifuged for $10 \mathrm{~min}$ at $12000 \mathrm{rpm}$. The DNA was resolved in $50 \mu \mathrm{l} \mathrm{TE}$ buffer $(10 \mathrm{mM}$ Tris $\mathrm{pH} 8.01$ $\mathrm{mM}$ EDTA- $\left.\mathrm{Na}_{2}\right) 10 \mathrm{~min}$ at $65^{\circ} \mathrm{C}$. RNase was added to a final concentration of $40 \mu \mathrm{g} / \mathrm{ml}$ and the tube incubated for $30 \mathrm{~min}$ at $37^{\circ} \mathrm{C}$. The DNA solution was diluted further with TE buffer to $200 \mu 1$ and extracted twice with an equal volume phenol/chloroform/isoamyl alcohol (25/24/1). The aqueous phase was transferred to 2.5 vols. ethanol $(100 \%)$ and 0.1 vol. sodium acetate $(3 \mathrm{M}$, $\mathrm{pH}$ 5) for $30 \mathrm{~min}$ on ice. The precipitate was then centrifuged (10 min $12000 \mathrm{rpm})$. The pellet was washed with $70 \%$ ethanol, air dried and resolved in $50 \mu 1$ TE buffer. $10 \mu \mathrm{g}$ DNA were loaded into dry wells of a $2 \%$ agarose gel (Ultrapure agarose, Life Technologies, Breda, Netherlands). After electrophoresis the gel was stained with ethidium bromide.

\subsection{FITC-Annexin V preparation}

Annexin $\mathrm{V}$ was prepared by cDNA recombinant techniques with plasmid pRH291, and purified as previously described (Maurer-Fogy et al., 1989). The preparation was more than $99 \%$ pure. FITC labelling was achieved by dialyzing Annexin $\mathrm{V}$ against a coupling buffer $(50 \mathrm{mM}$ sodium borate/ $\mathrm{NaOH}, \mathrm{pH} 9.0,150 \mu \mathrm{M} \mathrm{NaCl}$ and $1 \mathrm{mM}$ EDTA. Dialyzed Annexin V $(50 \mu \mathrm{M})$ was mixed with $50 \mu \mathrm{M}$ FITC isomer I (F7250, Sigma, St. Louis, MO) for $2 \mathrm{~h}$ at $37^{\circ} \mathrm{C}$. The coupling reac-
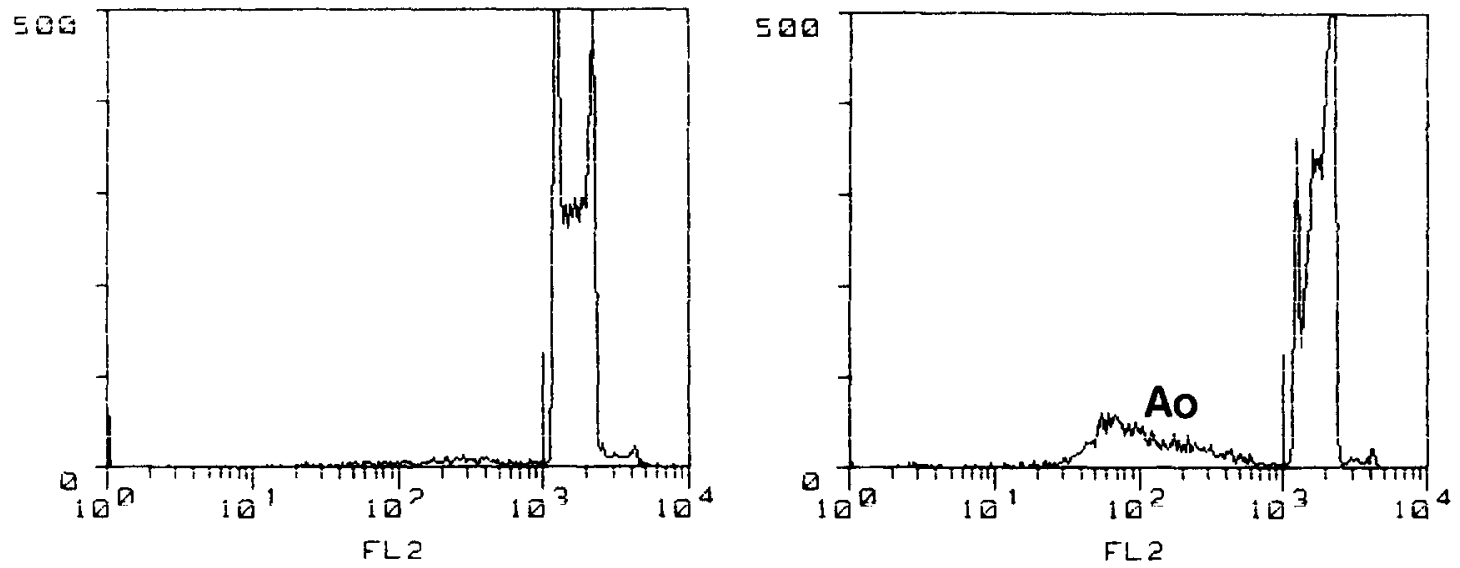

Fig. 2. DNA-FCM histograms of PI-stained HSB-2 cells at time 0 (left panel) and $8 \mathrm{~h}$ (right panel) after irradiation with 6 Gy. 
tion was then stopped by the addition of $100 \mathrm{mM}$ glycine. The mixture was first dialyzed against 50 $\mathrm{mM}$ Tris $/ \mathrm{HCl}, \mathrm{pH} 8.0,80 \mathrm{mM} \mathrm{NaCl}$ and $1 \mathrm{mM}$ EDTA and subsequently applied to a Mono $Q$ column (Pharmacia, Uppsala, Sweden). The bound proteins were eluted using a gradient of $\mathrm{NaCl}$. The eluted peaks were analyzed for protein content and absorbance at $492 \mathrm{~nm}$ (for FITC, $\left.\varepsilon^{492}=78000 \mathrm{~mol}^{-1} \cdot 1 \cdot \mathrm{cm}^{-1}\right)$. The stoichiometric 1:1 complex was identified and used for the ex-

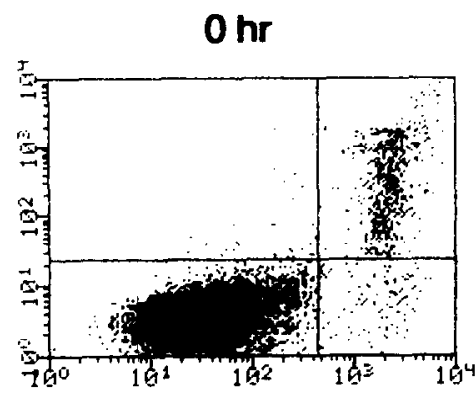

$\mathrm{R} 1=6.5 \%$

$R 2=1.0 \%$
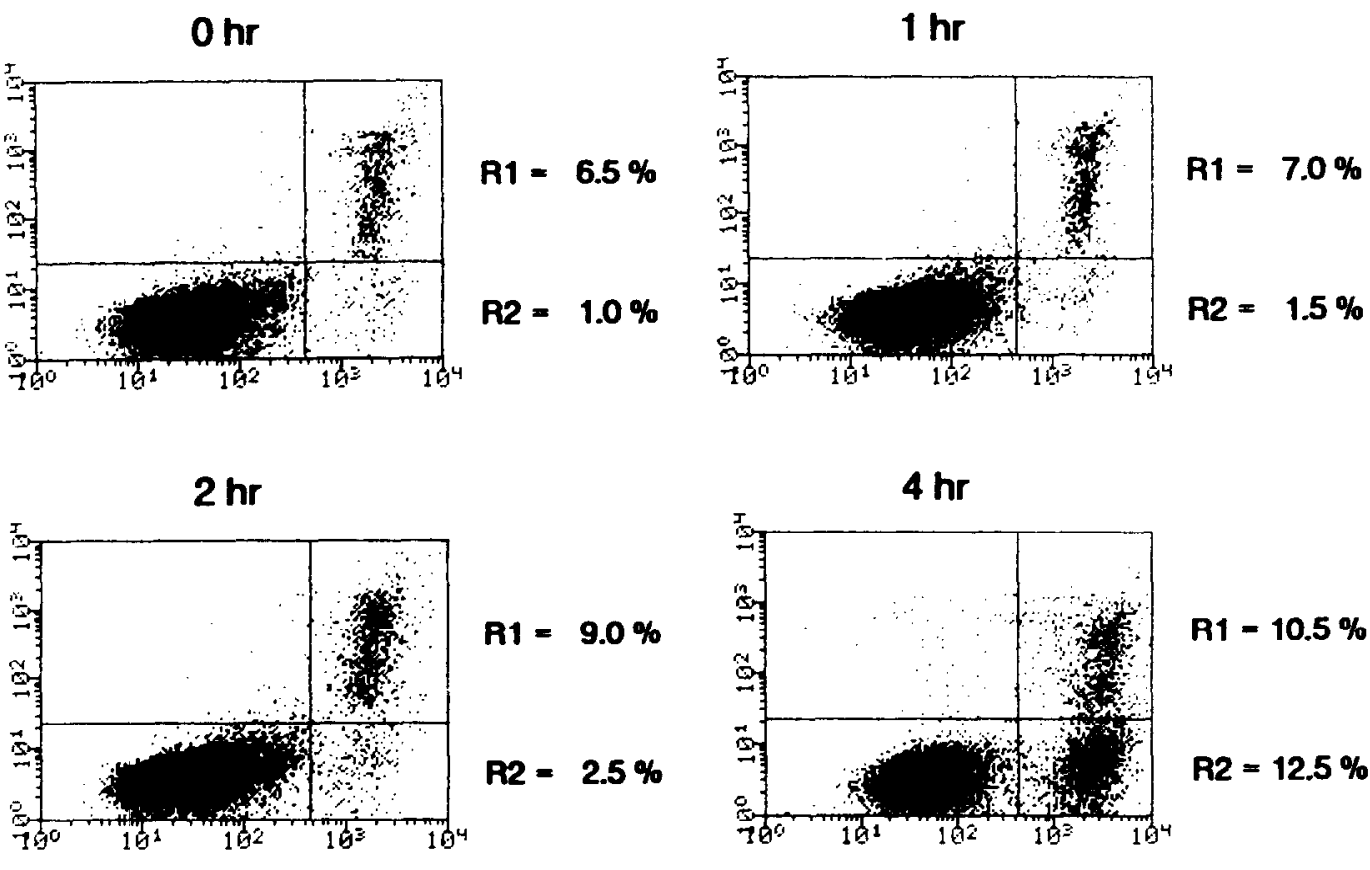

P1 $=10.5 \%$

$R 2=12.5 \%$

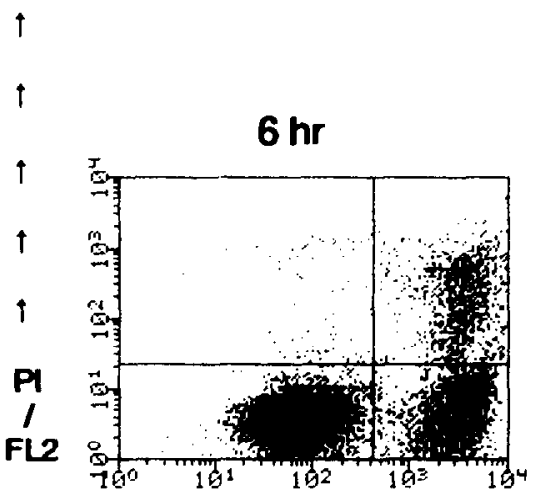

$R 1=12.0 \%$

$\mathrm{R} 2=23.5 \%$

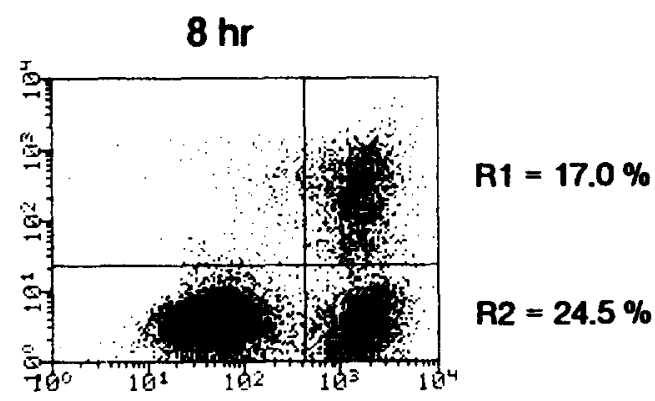

FL1 / FITC-ANNEXINE

Fig. 3. Contour diagram of FITC-Annexin V/PI flow cytometry of HSB-2 cells after 8 Gy irradiation for different time intervals. The lower left quadrants of each panels show the viable cells, which exclude PI and are negative for FITC-Annexin V binding. The upper right quadrants (R1) contain the non-viable, necrotic cells, positive for FITC-Annexin V binding and for PI uptake. The lower right quadrants (R2) represent the apoptotic cells, FITC-Annexin V positive and PI negative, demonstrating cytoplasmic membrane integrity. One representative experiment out of three is shown. 
periment. The FITC labelling had no deleterious effect upon the phospholipid binding properties of the FITC-Annexin complex, compared to the unlabelled Annexin, as analyzed by ellipsometry (Andree et al., 1990).

\subsection{FITC-Annexin $V / P I$ double staining}

Double staining for FITC-Annexin V binding and for cellular DNA using of PI was performed as follows. After washing twice with PBS, $1 \times 10^{6}$ cells were resuspended in binding buffer $(10 \mathrm{mM}$ Hepes/NaOH, pH 7.4, $140 \mathrm{mM} \mathrm{NaCl}, 2.5 \mathrm{mM}$ $\mathrm{CaCl}_{2}$ ). FITC-Annexin $\mathrm{V}$ was added to a final concentration of $1 \mu \mathrm{g} / \mathrm{ml}$ Annexin V. 0.1 vol. of PI $(10 \mu \mathrm{g} / \mathrm{ml}$ in binding buffer $)$ was added resulting in a final concentration of $1 \mu \mathrm{g} \mathrm{PI} / \mathrm{ml}$ cell suspension. The mixture was incubated for 10 min in the dark at room temperature and then measured by bivariate FCM using program Lysys 2. The reproducibility of the assay was tested in two ways. When HSB-2 cells were irradiated with $8 \mathrm{~Gy}$ and ten samples were measured $4 \mathrm{~h}$ later a mean \pm SD of $12.8 \pm 1.3 \% \mathrm{FITC}^{+} / \mathrm{PI}^{-}$cell population was observed. On the other hand when the lymphocytes of 12 healthy volunteers were isolated according to the technique described above and measured on day 0 and day 3 , means $\pm \mathrm{SD}$ of $1.9 \pm 1.0 \%$ and $4.3 \pm 2.8 \%$ of FITC $^{+} / \mathrm{PI}^{-}$cell populations were measured.

\section{Results}

\subsection{Light microscopy}

Necrotic cells show cytoplasmic vacuolisation, nuclear swelling, rupture of both nuclear and plasma membranes and appear as faintly stained cells with nuclear ghosts. In contrast, apoptotic cells show shrinking, chromatin clumping and nuclear fragmentation. In this case the cell membrane and cell organelles stay intact, although the plasma membrane often shows some blebbing. Nuclear collapse is the main indicator that the cell has undergone apoptosis. The various morphological characteristics are shown in Fig. 1. Fig. 1A shows intact HSB-2 cells. Fig. 1B shows cell necrosis induced by $24 \mathrm{~h}$ incubation of HSB-2 cells with sodium azide. Fig. $1 \mathrm{C}$ shows the morphology of cell necrosis, as observed in HSB-2 cells $24 \mathrm{~h}$ after irradiation. The appearance of the cells in Fig. 1D, $6 \mathrm{~h}$ after irradiation is characteristic for apoptosis.

A good correlation has been found between the radiation dose applied $(0,2,4,6,8 \mathrm{~Gy})$ and the percentages of apoptotic HSB-2 cells as observed by light microscopy in the cytocentrifuge preparations $6 \mathrm{~h}$ after irradiation amounts to 3, 5, 9,14 and $16 \%$ respectively.

\subsection{Hypo-diploid nuclei}

Apoptotic cells show diminished staining below the $G_{0} / G_{1}$ population of normal diploid cells. The DNA specific fluorochrome PI, identified a distinct hypo-diploid cell population, designated $A_{0}$ cells, and this was also observed during irradiation of HSB- 2 cells. Fig. 2 shows a representative DNA-histogram of HSB-2 cells as observed $8 \mathrm{~h}$ after irradiation with $6 \mathrm{~Gy}$. The percentages of hypo-diploid nuclei ( $\mathrm{A}_{\mathrm{o}}$ cells), as measured by DNA-FCM, in relation to the radiation dose applied were in agreement with the percentage of apoptotic cells as measured by light microscopy.

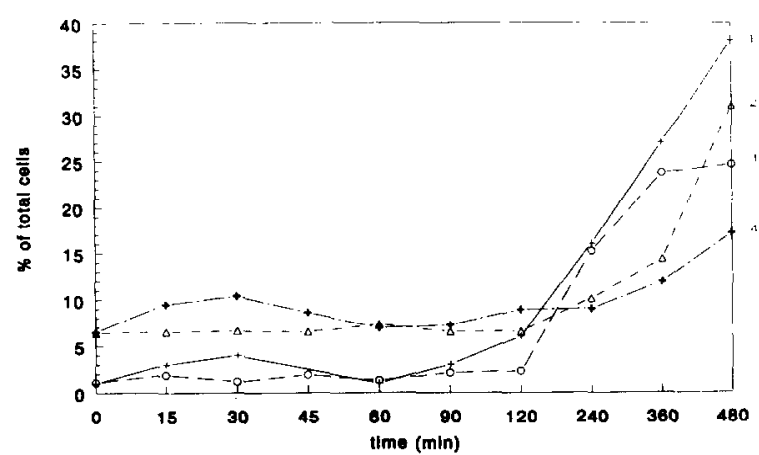

Fig. 4. Irradiation induced cell death over time measured with light microscopy, with DNA-FCM and with FITC-Annexin $\mathrm{V} / \mathrm{PI}$ bivariate FCM. HSB-2 cells were irradiated with $8 \mathrm{~Gy}$ and were studied at $O, 15,30,45,60,90 \mathrm{~min}$ and $2,4,6$ and 8 h later for morphological characteristics of apoptosis (1), hypo-diploid cell populations (2), FITC-Annexin $\mathrm{V}^{+} / \mathrm{PI}^{-}$ apoptotic cells (3) and FITC-Annexin $\mathrm{V}^{+} / \mathrm{PI}^{+}$necrotic cells (4). 


\subsection{FITC-Annexin V/PI bivariate FCM}

Apoptotic cells exclude all those dyes which are in use for cell viability assays, such as PI, while necrotic cells do not. In cells with a damaged cell membrane PI induces a red fluorescence of the DNA, whilst it is excluded by cells with a preserved cytoplasmin membrane. Hence during the initial phase of apoptosis the cells are still able to exclude PI and therefore do not show any red fluorescence signal, similar to that of living cells. Fig. 3 shows the results of bivariate FITC-Annexin V/PI FCM of HSB-2 cells after irradiation with $8 \mathrm{~Gy}$ for different time intervals.

HUMAN LYMPHOCYTES UNTREATED

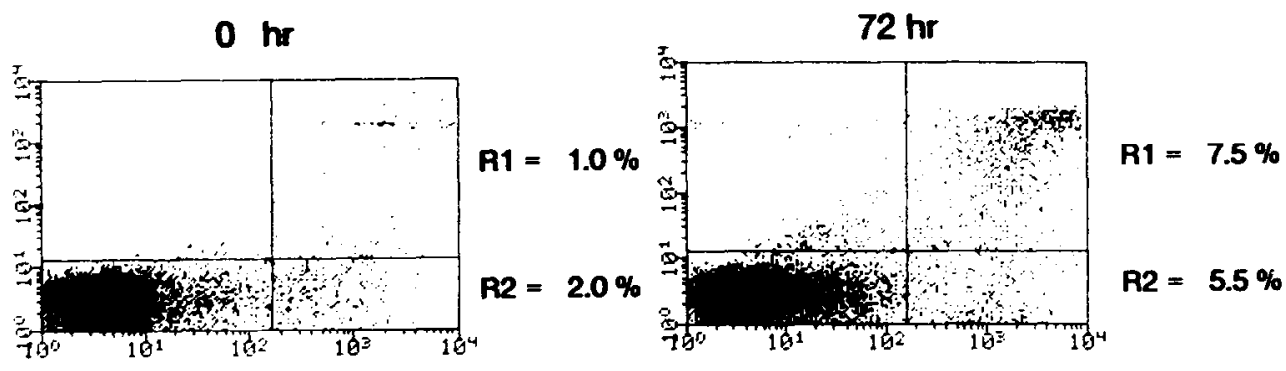

HUMAN LYMPHOCYTES EXPOSED TO DEXAMETHASONE
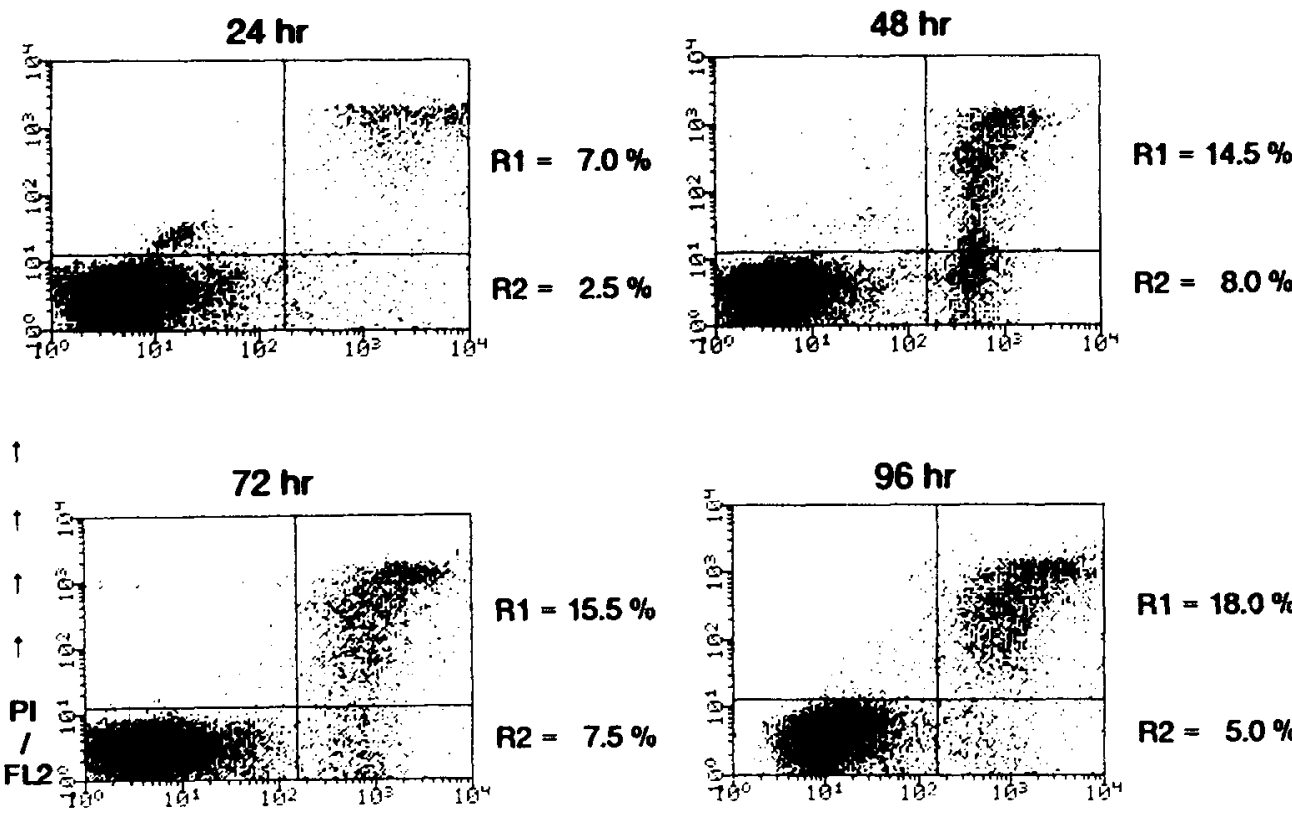

R1 $=18.0 \%$

$\mathrm{R} 2=5.0 \%$

FL1 / FITC-ANNEXINE

Fig. 5. Contour diagram of FITC-Annexin V/PI flow cytometry of human lymphocytes cultured for various time intervals with and without dexamethasone $(100 \mu \mathrm{M})$. For details see legend to Fig 3. One representative experiment out of three is shown. 
The lower left quadrant of the cytograms shows the viable cells, which exclude PI and are negative for FITC-Annexin V binding. The upper right quadrant represents the non-viable, necrotic cells, positive for FITC-Annexin $\mathrm{V}$ binding and showing PI uptake. The lower right quadrant represents the apoptotic cells, FITC-Annexin V positive and PI negative, demonstrating Annexin V binding and cytoplasmic membrane integrity. Fig. 4 shows the correlation over time between the FITC-Annexin V/PI bivariate FCM with the results of light microscopy and with the percentages of hypo-diploid $A_{0}$ cells in the same experiment.

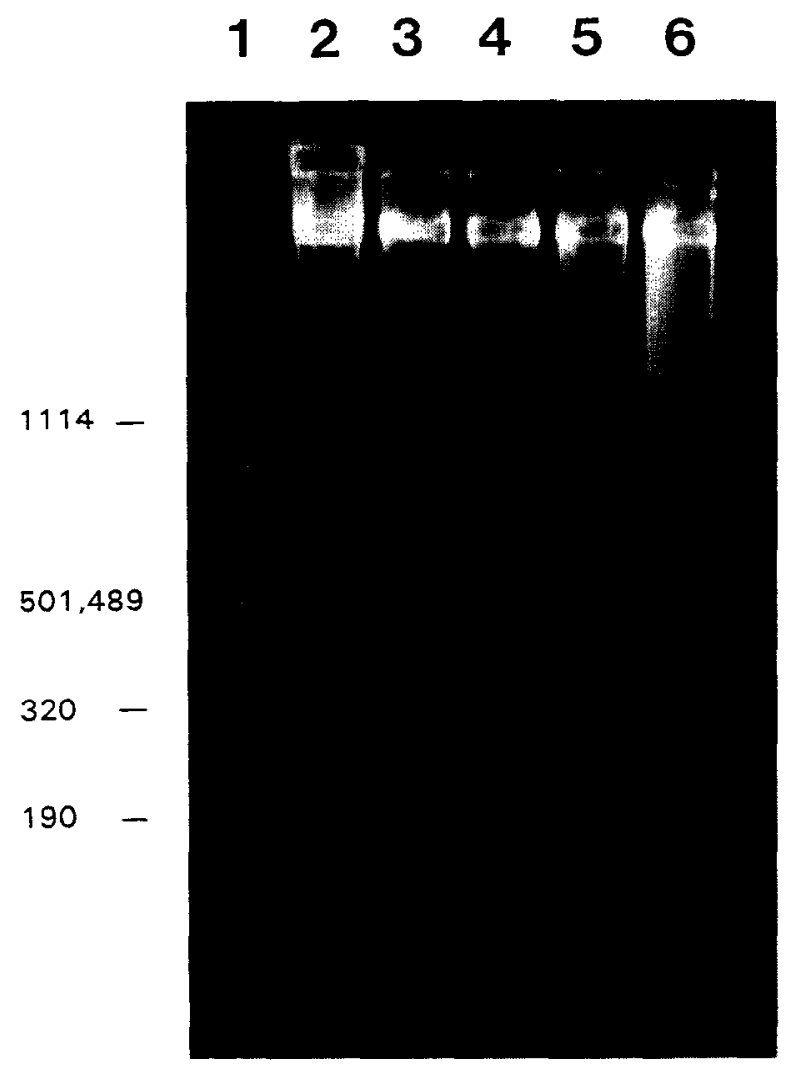

Fig. 6. Electrophoresis of DNA, extracted from cell fractions. The DNA of the cells, which were hypo-diploid, positive for apoptosis by light microscopy, and which exhibited Annexin V binding shows a ladder pattern characteristic for apoptosis. Lane 1: MW marker pUC BM $21 \times H p a I I$, pUC BM $21 \times$ DraI, HindIII. Lane 2: untreated HSB-2 cells. Lane 3-6: HSB-2 cells after 8 Gy irradiation for $0,4,6$ and $8 \mathrm{~h}$.
The FITC $^{+} / \mathrm{PI}^{-}$apoptotic cell population increased gradually from $<2 \%$ at $t=0$, to $2 \%$ after $2 \mathrm{~h}$ and to $15 \%$ after $4 \mathrm{~h}$. On the other hand, the $A_{0}$ cell population was increased after only $4 \mathrm{~h}$ to $10 \%$. The $\mathrm{FITC}^{+} / \mathrm{PI}^{+}$necrotic cell population increased only $8 \mathrm{~h}$ after irradiation to $17 \%$. Fig. 5 shows the results of bivariate FCM of lymphocytes exposed to dexamethasone. The FITC $^{+} / \mathrm{PI}^{-}$cell population increased after $48 \mathrm{~h}$ dexamethasone exposure, but the $\mathrm{A}_{\mathrm{o}}$ cell population increased after only $72 \mathrm{~h}$ (results not shown).

\subsection{DNA fragmentation}

The major biochemical hallmark of apoptotic cell death is the cleavage of chromosomal DNA at inter-nucleosomal sites into fragments or multiples of about $200 \mathrm{bp}$. To be sure that the cells under investigation really had undergone apoptosis, the irradiated and dexamethasone treated cells were assayed for the presence of fragmented DNA. As demonstrated in Fig. 6 after irradiation with 8 Gy for various times HSB-2 cells (identified as being apoptotic on the basis of light microscopy, DNA FCM (hypo-diploid $A_{0}$ cells) and Annexin- $V$ binding) showed a typical DNA ladder pattern following electrophoresis. This demonstrates that morphology, DNA fragmentation and Annexin $\mathrm{V}$ binding correlate during apoptosis.

\section{Discussion}

The discovery of Annexin $\mathrm{V}$ and its purification and expression in Escherichia coli (Reutelingsperger et al., 1985; Maurer-Fogy et al., 1989) has provided a $\mathrm{Ca}^{2+}$-dependent phospholipid-binding protein with high affinity for PS (Andree et al., 1990; Tait et al., 1989). In eukaryotic cells, PS is predominantly located in membrane leaflets, facing the cytosol (Op den Kamp, 1979) and platelets maintain a similar phospholipid asymmetry under resting conditions. Activation of platelets may result in surface exposure of PS. Thiagarajan and Tait (1990) showed that Annexin $\mathrm{V}$ binds to platelets only if these are stimu- 
lated by agonists that are able to induce PS exposure. Annexin $\mathrm{V}$ can be conjugated to the fluorochrome FITC without impairing its phospholipid binding properties and hence it can be a valuable tool for studying the homeostasis of membrane asymmetry in eukaryotic cells. Recently Fadok et al. (1992) reported that cells expose PS during apoptosis. This led us to postulate that Annexin V would discriminate between non-apoptotic and apoptotic cells and could be used to develop a flow cytometric assay for apoptosis. Because PS exposure also takes place during cell necrosis, the Annexin $\mathrm{V}$ binding assay was combined with a non-vital dye exclusion test in order to collect information about the integrity of the cell membrane, which fails early during necrosis whilst remaining intact during the initial phase of apoptosis.

As demonstrated in Figs. 3-5 the Annexin V assay permits kinetic measurements of the number of apoptotic cells in relation to time after insult. Fig. 3 and Fig. 4 show the results of applying the Annexin V assay, to indicate the numbers of apoptotic and necrotic cells in relation to time elapsed after irradiation. HSB-2 cells show maximal apoptosis between 4 and $8 \mathrm{~h}$ after irradiation and become necrotic between 8-24 h. Human peripheral lymphocytes remained intact after treatment with dexamethasone for $24 \mathrm{~h}$. However, there was then an increase in the percentage of apoptotic cells with a maximum of $8 \%$ at $48 \mathrm{~h}$, after which the percentage decreased. Fig. 5 suggests that normal peripheral human lymphocytes are relatively resistant to dexamethasone exposure, in contrast to the high sensitivity of thymocytes reported in the in the literature (Wyllie, 1980). After $48 \mathrm{~h}$ of dexamethasone treatment there was some discrepancy between the number of hypo-diploid and Annexin $\mathrm{V}$ positive cells. The $A_{o}$ cells outnumbered the Annexin $\mathrm{V}$ positive cells, which probably indicates that the Nicoletti assay also measures cells which have lost their membrane integrity and are becoming necrotic.

Three traditional methods (microscopy, DNA-flow cytometry, DNA electrophoresis) have been compared with the Annexin binding assay, with regard to their ability to detect apoptotic cells. The novel Annexin binding assay, in combination with a non-vital dye exclusion test, appears to be sensitive, correlates with the other tests and is easy to perform. Until now morphological assessment has been the most reliable method for the identification of individual apoptotic cells. However this method is subjective and offers only a numerical impression of the occurrence of apoptosis in cytological preparations. In particular it is not suitable for kinetic studies or statistical analysis. The method, described by Nicoletti et al. (1991) for quantitative analysis of hypo-diploid cells using DNA-FCM, is easy to perform and gives a reliable estimate of the number of apoptotic cells. However, it measures only cells, which have already reached the stage where a substantial amount of the DNA has been fragmented and leaked from the cell or has been altered and lost staining capacity. Hence this method provides no information about the number of apoptotic cells which are in the initial phase of the process. Furthermore, because of the cell processing needed, the plasma membrane is disrupted with loss of the cell markers required for cell identification. Flow cytometric analysis of apoptosis in non-fixed preparations, as recently reviewed by Darzynkiewicz et al. (1992) and Telford et al. (1994), exploits alterations in cell size and differences in fluorescence intensity obtained with Hoechst 33342, acridine orange, PI and/or rhodamine 123. The quantitation of apoptosis in these methods is based upon differences between live, apoptotic and necrotic cells with respect to membrane permeability, lipid bilayer packing density, $p$-glucoprotein membrane or lysosomal pump activities or mitochondrial transmembrane potentials. These differences are rather subtle and gradual and hardly specific for the apoptotic process. Measurement of DNA fragments (Facchinetti et al., 1991; Olive et al., 1993) provides a sensitive assay for the detection of DNA fragmentation, but this method is time consuming, lacks cell specificity, is qualitative rather than quantitative and does not offer kinetic information about the apoptotic process.

The two-parameter FCM method described here permits the detection of the early phases of apoptosis before the loss of cell membrane in- 
tegrity. Moreover, it is possible to measure the kinetics of the process over time and in relation to the cell cycle. We have established this method with peripheral lymphocytes and the cell line HSB-2 but exposure of Annexin V binding sites during the process of apoptosis has also been observed in germinal centre B cells (Koopman et al., 1994), in peripheral neutrophils (Homburg et al., 1994) and in rat thymocytes (Reutelingsperger, unpublished observation). Hence, loss of plasma membrane asymmetry seems to be a universal phenomenon of apoptosis and consequently the described assay is likely to be applicable to all cell types.

\section{Acknowledgements}

The authors thank Dr. M.G. Havenith (Department of Pathology), Dr. J.H. Meerwaldt (Department of Radiotherapy) for their indispensable cooperation throughout this study. The authors are grateful to Cecile Maassen for her excellent technical assistance in preparing FITCAnnexin V, Ellen Kalsbeek-Batenburg for performing FCM analysis, Arnold Leemhuis for performing the cell cultures and Sia Timmerman for her excellent secretarial assistence.

\section{References}

Andree, H.A., Reutelingsperger, C.P., Hauptmann, R., Hemker, H.C., Hermens, W.T. and Willems, G.M. (1990) Binding of vascular anticoagulant alpha (VAC alpha) to planar phospholipid bilayers. J. Biol. Chem. 265, 4923.

Arends, M.J., Morris, R.G. and Wyllie, A.H. (1990) Apoptosis. The role of the endonuclease. Am. J. Pathol. 136, 593.

Begg, A.C., McNally, N.J., Shrieve, D.C. and Kärcher, H. (1985) A method to measure the duration of DNA synthesis and the potential doubling time from a single sample. Cytometry 6, 620 .

Darzynkiewicz, Z., Bruno, S., DelBino, G., Gorczyca, W., Hotz, M.A., Lassota., P. and Traganos, F. (1992) Features of apoptotic cells measured by flow cytometry. Cytometry 13, 795 .

DelVecchio, M.T., Leoncini, L., Buerki, K., Kraft, R., Megha, T., Barbini, P., Tosi, P. and Cottier, H. (1991) Diffuse centrocytic and/or centroblasticmalignant non-Hodgkin's lymphomas: comparison of mitotic and pyknotic (apoptotic) indices. Int. J. Cancer 47, 38.
Facchinetti, A., Tessarollo, L., Mazzocchi, M., Kingston, R., Collavo, D. and Biasi, G. (1991) An improved method for the detection of DNA fragmentation. J. Immunol. Methods $136,1251$.

Fadok, V.A., Voelker, D.R., Campbell, P.A., Cohen, J.J., Bratton, D.L. and Henson, P.M. (1992) Exposure of phosphatidylserine on the surface of apoptotic lymphocytes triggers specific recognition and removal by macrophages. J. Immunol. 148, 2207.

Geisow, M.J., Fritsche, U, Hexham, J.M., Dash, B. and Johnson, T. (1986) A consensus amino-acid sequence repeat in Torpedo and mammalian $\mathrm{Ca}^{2+}$-dependent membrane-binding proteins. Nature 320, 636.

Gerdes, J., Schwab, U., Lemke, H. and Stein, H. (1983) Production of a mouse monoclonal antibody reactive with human nuclear antigen associated with cell proliferation. Int. J. Cancer 31, 13.

Hall, P.A. and Levison, D.A. (1990) Review: assessment of cell proliferation in histological material. J. Clin. Pathol. 43, 184.

Homburg, C.H.E., de Haas, M., von dem Borne, A.E.G.Kr., Verhoeven, A.J., Reutelingsperger, C.P.M. and Roos, D. (1994) Human neutrophils lose their surface Fc $\gamma$ RIII and acquire Annexine $\mathrm{V}$ binding sites during apoptosis in vitro. Blood, in press.

Hotz, M.A., Gong, J., Traganos, F. and Darzynkiewicz, Z. (1994) Flow cytometric detection of apoptosis: Comparison of the assays of in situ DNA degradation and chromatin changes. Cytometry 15, 237.

Koopman, G., Reutelingsperger, C.P.M., Kuijten, G.A.M., Keehnen, R.M.J., Pals, S.T. and Van Oers, M.H.J. (1994) Annexine $\mathrm{V}$ for flow cytometric detection of phosphatidylserine expression on $\mathrm{B}$ cells undergoing apoptosis. Blood 84, 1415.

Leoncini, L., DelVecchio, M.T., Megha, T., Barbini, P., Galieni, P., Pileri, S., Sabattini, E., Gherlinzoni, F., Tosi, P., Kraft, R. and Cottier, H. (1993) Correlations between apoptotic and proliferative indices in malignant nonHodgkin's lymphomas. Am. J. Pathol. 142, 755.

Maurer-Fogy, I., Reutelingsperger, C.P., Pieters, J., Bodo, G., Stratowa, C. and Hauptmann, R. (1989) Cloning and expression of cDNA for human vascular anticoagulant, a $\mathrm{Ca}^{2+}$-dependent phospholipid-binding protein. Eur. J. Biochem. 174, 585.

Meyaard, L., Otto, S.A., Jonker, R.R., Mijnster, M.J., Keet, R.P.M. and Miedema, F. (1992) Pogrammed death of T cells in HIV-1 infection. Science $257,217$.

Miller, S.A., Dykes, D.D. and Polesky, H.F. (1988) A simple salting out procedure for extracting DNA from human nucleated cells. Nucl. Acids Res. 1215.

Nicoletti, I., Migliorati, G., Pagliacci, M.C., Grignani, F. and Riccardi, C. (1991) A rapid and simple method for measuring thymocyte apoptosis by propidium iodide staining and flow cytometry. J. Immunol. Methods 139, 271.

Olive, P.L., Frazer, G. and Banáth, J.P. (1993) Radiation-induced apoptosis measured in TK6 human B lymphoblast cells using the comet assay. Radiat. Res. 136, 130 
Op den Kamp, J.A.F. (1979) Lipid asymmetry in membranes. Ann. Rev. Biochem. 48, 47.

Ormerod, M.G., Sun, X.-M., Brown, D., Snowden, R.T. and Cohen, G.M. (1993) Quantification of apoptosis and necrosis by flow cytometry. Acta Oncol. 32, 417.

Pytela, R., Pierschbaccher, M.D. and Ruoslahti, E. (1985) A $125 / 115 \mathrm{kDa}$ cell surface receptor specific for vitronectin interacts with the Arg-Gly-Asp adhesion sequence derived from fibronectin. Proc. Natl. Acad. Sci. USA 82, 5766.

Raynal, P.R. and Pollard, H.B. (1994) Annexins: the problem of assessing the biological role for a gene family of multifunctional calcium- and phospholipid-binding proteins Biochim. Biophys. Acta 1197, 63.

Reutelingsperger, C.P., Hornstra, G. and Hemker, M.C. (1985) Isolation and partial purification of a novel anticoagulant from arteries of human umbilical cord. Eur. J. Biochem. 151,625 .

Sarraf, C.E. and Bowen, I.D. (1988) Proportions of mitotic and apoptotic cells in a range of untreated experimental tumours. Cell Tissue Kinet. 21, 45.

Savill, J.S., Fadok, V., Henson, P.M. and Haslett, C. (1993) Phagocytic recognition of cells undergoing apoptosis. Immunol. Today 14, 131.

Schmid, I., Uitlenbogaart, C.H. and Giorgi, J.V. (1994) Sensitive method for measuring apoptosis and cell surface phenotype in human thymocytes by flow cytometry. Cytometry $15,12$.

Schroit, A.J. and Zwaal, R.F.A. (1991) Transbilayer movement of phospholipids in red cells and platelet membranes. Biochim. Biophys. Acta 1071, 313.

Tait, J.F., Gibson, D. and Fujikawa, K. (1989) Phospholipid binding properties of human placental anticoagulant protein-I, a member of the lipocortin family. J. Biol. Chem. $264,14$.
Telford, W.G., King, L.E. and Fraker, P.J. (1991) Evaluation of glucocorticoid-induced DNA fragmentation in mouse thymocytes by flow cytometry. Cell Prolif. 24, 447.

Telford, W.G., King, L.E. and Fraker, P.J. (1992) Comparative evaluation of several DNA binding dyes in the detection of apoptosis-associated chromatin degradation by flow cytometry. Cytometry 13, 137.

Telford, W.G., King. L.E. and Fraker, P.J. (1994) Rapid quantitation of apoptosis in pure and heterogeneous cell populations using flow cytometry. J. Immunol. Methods 172,1 .

Thiagarajan, P. and Tait, J.F. (1990) Binding of Annexin $\mathrm{V}$ /placental anticoagulant protein to platelets. J. Biol. Chem. 265, 17420.

Woods, A.L., Hall, P.A., Shepherd, N.A., Hanby, A.M. Waseem, N.H., Lane, D.P. and Levison, D.A. (1991) The assessment of proliferating cell nuclear antigen (PCNA) immuno-staining in primary gastrointestinal lymphomas and its relationship to histological grade, $S+G 2+M$ phase fraction (flow cytometric analysis) and prognosis. Histopathology 19, 21.

Wijsman, J.H., Jonker, R.R., Keijzer, R., Van de Velde, C.J.H., Cornelisse, C.J. and Van Dierendonck, J.H. (1993) A new method to detect apoptosis in paraffin sections: In situ end-labeling of fragmented DNA. J. Histochem. Cy tochem. 41,7 .

Wyllie, A.H. (1980) Glucocorticoid-induced thymocyte apoptosis is associated with endogenous endonuclease activation. Nature 284, 555.

Wyllie, A.H., Kerr, J.F.R. and Currie, A.R. (1980) Cell death: The significance of apoptosis. Int. Rev. Cytol. 68, 251. 